\title{
Isolated Enchondroma of Atlas
}

\author{
Atlasin İzole Enkondromu
}

\author{
Abrar Ahad WANI, Javeed Iqbal ZARGAR, Altaf U RAMZAN, Nayil K MALIK, Iqbal LONE, MA WANI \\ Sheri- Kashmir Institute of Medical Sciences, Department of Neurosurgery, Jammu \& Kashmir, India
}

Correspondence address: Abrar Ahad WANI / E-mail: abrarwani@rediffmail.com

\begin{abstract}
Compression at the craniovertebral junction because of tumors is not a very common entity. The commonest tumors present here are neurofibroma and meningioma. Any vertebral tumour can be present at this location. Benign bony tumors are very uncommon at this location and amongst these enchondromas are exceptionally rare. Enchondromas are rare bony tumours of chondrogenic origin. These are benign tumours with a propensity for malignant transformation. There are four histological types: osteochondromas, enchondromas, chondroblastoma and chondromyxoid fibroma. Enchondromas are often asymptomatic because of their slow growth but may have varied presentation. An enchondroma may occur as an individual tumor or as several tumors together. We here report a case of enchondroma arising from the atlas and causing myelopathy. The best treatment is complete excision which we could achieve in our case.
\end{abstract}

KEYWORDS: Enchondroma, Atlas, Chandrogenic tumour

öz

Kranyovertebral bileşkenin tümörler nedeniyle kompresyonu çok sık değildir. Burada bulunan en sık tümörler nörofibromlar ve menengiomlardır. Bununla beraber herhangi bir vertebra tümörü bu lokasyonda bulunabilir. Benign kemik tümörleri bu bölgede nadirdir ve bunların arasında enkondromlar özellikle nadirdir. Enkondromlar kondrojenik kaynaklı nadir kemik tümörleridir. Bunlar malign transformasyon eğilimli benign tümörlerdir. Dört histolojik tipi vardır; Osteokondromlar, enkondromlar, kondroblastomlar ve kondromiksoid fibromlar. Enkondromlar sıklıkla asemptomatiktirler çünkü yavaş büyürler fakat çeşitli şekillerde kendilerini gösterebilirler. Bir enkondrom bireysel olabilir veya birçok tümör birlikte bulunabilir. Biz burada atlastan kaynaklanan ve myelopatiye neden olan bir enkondrom vakası sunuyoruz. En iyi tedavi bizim de vakamızda uygulayabildiğimiz gibi komplet eksizyondur.

ANAHTAR SÖZCÜKLER: Enkondrom, Atlas, Kindrojenik tümör

\section{INTRODUCTION}

Enchondroma is one of the rare tumours of spine (3). The symptoms are most commonly pain and swelling at the site of the lesion, but compression of the cord can cause myelopathy $(4,5,13,14)$. An enchondroma may occur as an individual tumor or several tumors together. The lesion appears as a welldefined central region of rarefaction in the medullary cavity of bone, which may contain mottled calcifications. Microscopic examination of the specimen reveals outer perichondrium, cartilage cap and underlying stalk. The cellularity of the lesion may vary, ranging from an almost acellular matrix to a hypercellular lobular arrangement. The ground substance is usually hyaline in appearance but may appear myxoid or even mucinous $(3,7,15)$. Curettage is the traditional treatment of enchondromas, but block excision of tumor with margins of normal bone is the best treatment which we could achieve in our case.

\section{CASE REPORT}

A 25-year-old male presented with history of progressive onset of quadriparesis for the past 8 months. There was no history of trauma. The patient was evaluated and clinical examination revealed all the features of cervical myelopathy with Harsh grade 4 myelopathy. CT scan showed a bony lesion arising from the posterior arch of the atlas (Figure 1A,B). $M R I$, in addition to confirming the $C T$ findings, also confirmed that there was significant compression of the spinal cord by this lesion (Figure 2). The patient was operated upon through a posterior midline approach. A well-defined bony lesion was found to be arising from the arch of the atlas, causing significant compression at the cervico-medullary junction. There was absence of granulation tissue and the dura was intact. The lesion was excised completely. Histopathological examination of the specimen showed outer perichondrium, cartilage cap and underlying stalk. Endochondral ossification was also seen at the base which is a normal feature and should not to be interpreted as a malignancy invading the stalk (Figure 3).

Postoperative CT scan confirmed complete excision of the lesion (Figure 4). The patient was followed up for nine months. A significant improvement of symptoms was found though spasticity was still present (Harsh grade 3 ). 


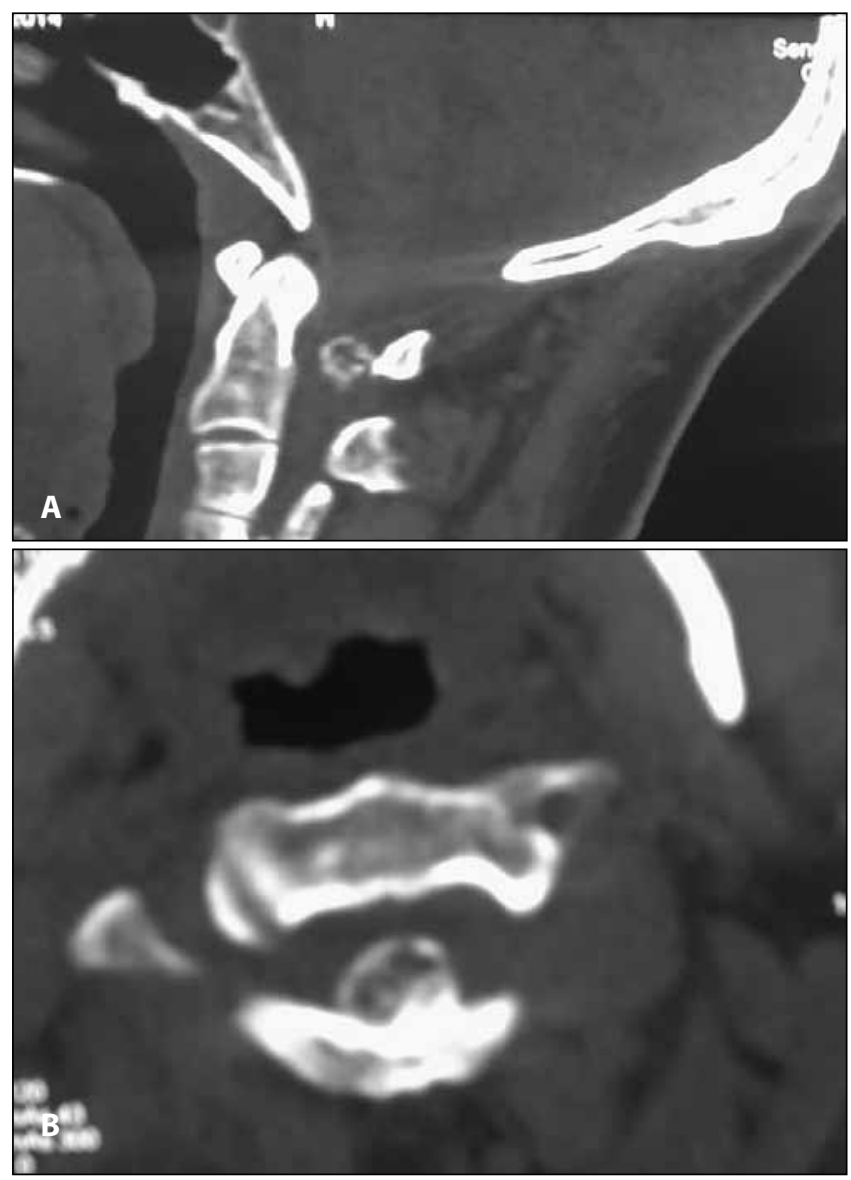

Figure 1A,B: CT scan showing well defined tumour arising from the anterior surface of the posterior arch of the atlas.

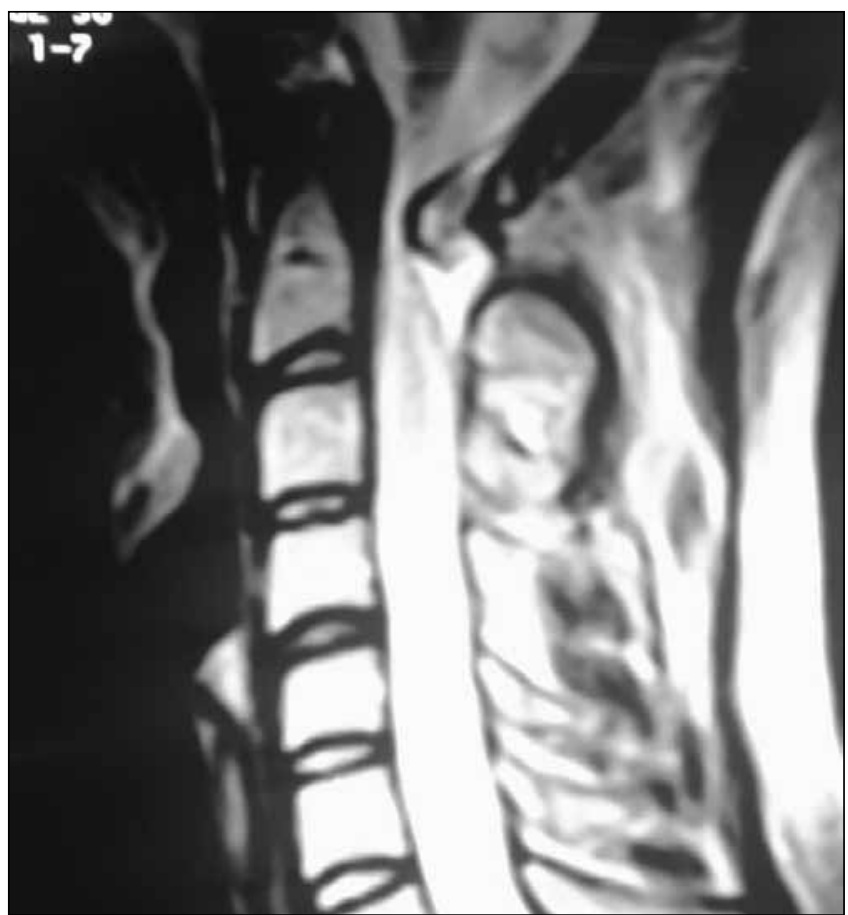

Figure 2: Sagittal T2-weighted MRI revealing compression of the cervico-medullary junction posteriorly by the tumour.

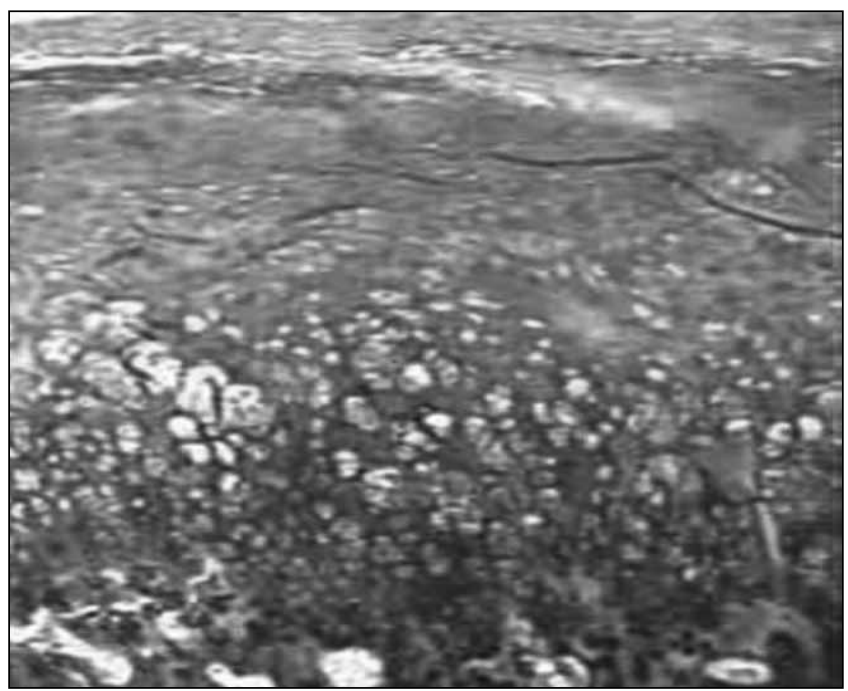

Figure 3: Enchondroma showing the outer perichondrium, cartilage cap and underlying stalk. A variable amount of endochondral ossification occurs at the bone/cartilage interface. Endochondral ossification is often seen at the base. This is a normal feature and should not be interpreted as a malignancy invading the stalk.

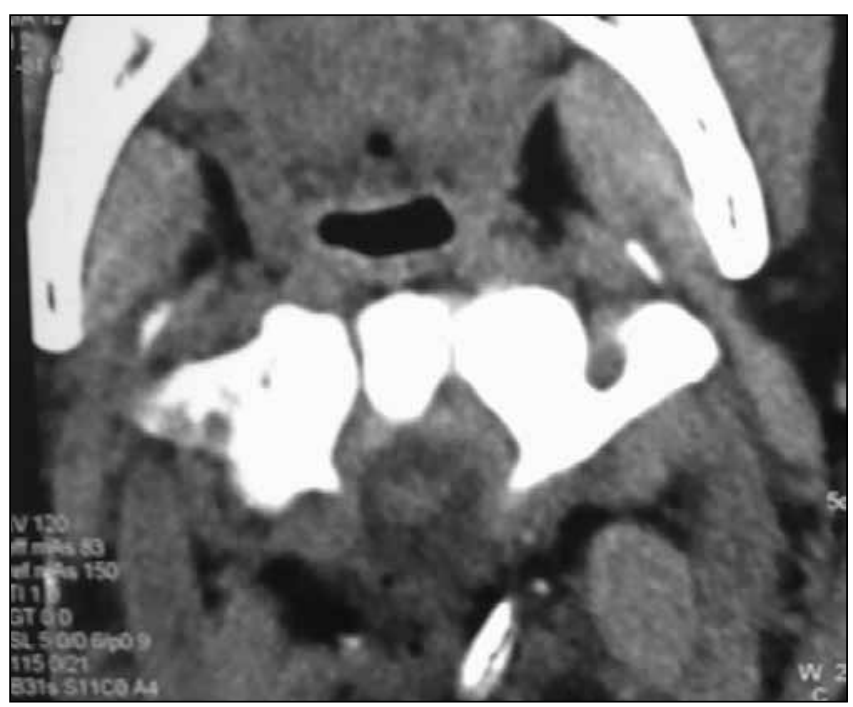

Figure 4: Postoperative CT scan showing complete excision of the tumor.

\section{DISCUSSION}

There are many ways of classifying benign chondrogenic tumours, and the widely accepted classification is the one proposed by Lichtenstein $L$ (6). There are four histological types in this classification; osteochondromas, enchondromas, chondroblastoma and chondromyxoid fibroma. Each type is distinct in its frequency and location of occurrence. Though there may be clinical similarities, the $x$-ray presentation, histopathology and propensity to undergo malignancy vary a lot according to the subtype. Enchondromas are often asymptomatic because of their slow growth. 
Symptoms are most commonly pain and swelling at the site of the lesion. Patients presenting with pathological fractures may sometimes on investigation reveal the presence of enchondromas. Discovery of such tumors is sometimes incidental on x-rays taken for some other complaints. A case of sudden death resulting from partial transection of the cord by an osteochondroma of odontoid process was reported by Rose and Fekete (13). J. Jullien et al. reported a case of cervical cord compression by solitary osteochondroma of the atlas (5). Solitary enchondroma of the vertebral body with cord compression has rarely been reported. Nag and Falconer reported a case of enchondroma of the $L 4$ vertebral body causing bilateral sciatica from compression of the cauda equina (10). A case of spastic paraparesis was described by Slowick et al. in a 13 year old girl with enchondroma of the cervical spine (14). A similar case involving the $L 4$ vertebral body of a 10-year-old girl was described by Herndon and Cohen (4).

An enchondroma may occur as an individual tumor or as several tumors together. The conditions that involve multiple lesions including the following:

Ollier's disease (enchondromatosis)-when multiple sites in the body develop the tumours.

Maffucci syndrome-a combination of multiple tumors and angiomas.

Solitary enchondromas are most often seen in the age group of 20-40 years. Oliver's disease is usually detected at 0-10 years.

There is no sex or racial predilection in these tumours. Bell listed all reported cases of cartilaginous tumour of spine from 1897 to 1968 . In his review of 69 cases, $50 \%$ of the cartilaginous spinal tumours were reported to be enchondromas. However as Bell points out, the differentiation between enchondromas and osteochondromas was not often possible because of lack of histological and operative detail (2). Of 15 benign cartilaginous tumors of spine in Dalhins' series of five thousand bone tumors only three were enchondromas (3). Multiple chondromas as in Oliver's disease and Maffucci syndrome occurred in $16 \%$ of cases of Dalhins series. Only $2 \%$ of chondromas were noted to be located in vertebral column in Dahlin's series. It is very rare for these tumours to produce neurological symptoms (3).

On plain X-ray films the lesion appears as well-circumscribed central region of rarefaction in the medullary cavity of the bone, which may contain mottled calcifications. An unusual occurrence may be ossification. Usually there is expansion of overlying cortical bone which is quite normal to find in many cases, but lysis of cortex over an underlying enchondroma should be taken as a suspicious sign of malignancy. The lesion replaces normal bone with mineralized or unmineralized hyaline cartilage, thereby generating a lytic pattern on radiographs. Some authors have suggested that an enchondroma measuring more than $7 \mathrm{~cm}$ in diameter should be inspected closely for signs of sarcomatous change $(3,7)$. MRI findings may be useful in distinguishing enchondromas in the long bones from bone infarcts. Typically bone infarcts are encapsulated by a serpiginous ring of decreased signal intensity on T1and T2 weighted images. Frequently this ring is subtended by a high signal intensity line. This finding has been called the double line sign (16). In addition, MRI is used to rule out any associated abnormalities of spinal cord and roots.

Enchondromas are cartilage-caped bony projections, and are benign tumours that unusually arise in the medullary cavity of bone from heterotopic cartilaginous cell rests. The lesions likely arise from cartilaginous rests that are displaced from growth plate. Complete transgression through the cortex with a soft tissue component is highly suggestive of malignancy. Chondrosarcoma is the most common malignant transformation. Histologically the enchondromas show round rather than uniform nucleus, much like those seen in normal hyaline cartilage. Cells with large nuclei are uncommon and suggest malignancy. The cellularity of the lesion may vary, ranging from an almost acellular matrix to a hypercellular lobular arrangement.The ground substance is usually hyaline in appearance but may appear myxoid or even mucinous. Calcific deposits are seen at sites of degeneration. Malignant transformation in the absence of multiple chondromatosis is quite rare $(3,7,15)$.

Curettage is the traditional treatment of enchondromas and some authors recommend chemical cauterization of the remaining cavity. Solid bone graft or bone chips may be placed in the defect. The frequency of recurrence is quite high. The tumor is essentially insensitive to radiotherapy and this may add to problems by causing diffuse myelitis in spinal lesions. Block excision of the tumor with margins of normal bone whenever possible is the worldwide accepted regime for the treatment of enchondromas.

\section{REFERENCES}

1. Ajay Pal Singh, Arun Pal Singh, Surbhi Mahajan: Periosteal chondroma of the sacrum. Can J Surg 51(5): E105-E106, 2008

2. Bell MS: Benign cartilaginous tumors of the spine. A report of one case together with a review of literature. Br J Surg 58:707-711, 1971

3. Dahlin DC: Bone tumors. 2nd ed. Charles C Thomas. Illinois: Springfield 1967:28-37

4. Herndon JH, Cohen J: Chondroma of lower vertebra in a child. J Bone Joint Surg (Am), 52-a:1241-1247, 1970

5. Julien J, Riemens V, Vital C, Lagueny A, Miet G: Cervical cord compression by solitary osteochondroma of the atlas. Neurol Neurosurg Psychiatry 41(5): 479-481, 1978

6. Lichtenstein L: Classification of primary tumors of bone. Cancer, 4: 335-341, 1951

7. Lichtenstein L: Bone tumors. St. Louis: Mosby Co, 1972:29-38

8. Loftus CM, Rozario RA, Prager R, Scott RM: Solitary osteochondroma of T4 with thoracic cord compression. Surg Neurol 13:355-357, 1980 
9. MacGee EE: Osteochondroma of cervical spine, A cause of transient quadriplegia. Neurosurgery 4:259-260,1979

10. Nag TK, Falconer MA: Enchondroma of the vertebral body: Report of a case causing bilateral sciatica. Br J Surg 53:1067-1071, 1966

11. O'Connor GA, Roberts TS: Spinal cord compression by an osteochondroma in a patient with multiple osteochondromatosis, J Neurosurg 60:420-423, 1984

12. Palmer FJ, Blum PW: Osteochondroma with spinal cord compression: Report of three cases, J Neurosurg 52: 842-845, 1980
13. Rose EF, Fekete A: Odontoid osteochondroma causing sudden death: Report of a case and review of literature. Am J Clin Path 42: 606-609, 1964

14. Slowick T, Bittner-Manioka M, Grochowski W: Chondroma of the cervical spine: Case report. J Neurosurg 29:276-278, 1968

15. Spjut HJ, Dorfman HD, Fechner RE, Akerman LV: Tumors of bone \& cartilage (Atlas of Tumor Pathology) 2nd series, fascicle 6 . Washington D.C: Armed Forces Institute of Pathology 1971

16. Thomas ML, Andress MR: Osteochondroma of cervical spine causing cord compression. Br J Radiol 44:549-550, 1971 